\title{
Study of the autonomic function in pregnancy
}

\section{Estudo da função autonômica em gestantes}

\author{
Wagner Santos Araújo', Jefferson Petto², Alan Carlos Nery dos Santos³, Francisco Thiago Oliveira de Oliveira³, \\ Cauê Santos da Mata ${ }^{1}$, João Carlos Mantese ${ }^{4}$, Maria Cristina Cury ${ }^{4}$, Dirce Maria Sigulem ${ }^{4}$, Guilliano Gardenghi ${ }^{5}$
}

\begin{abstract}
Introduction: Pregnancy is characterized by physiological changes related to the formation of an ideal environment for the fetus. This period is not unusual occur deviations from normality, as well as imbalance between the various body systems, especially the autonomic nervous system, which can result in pathological conditions. Objective: To evaluate the cardiovascular autonomic function and in accordance with gestational age pregnant women in the 1st, 2nd and 3rd quarter, by studying the Heart Rate Variability (HRV). Method: Were evaluated 20 pregnant women enrolled in a Basic Health Unit. The protocol was divided into two phases with 10 minutes duration in the left lateral decubitus (LLD) and 10 minutes in the sitting position (SEDT). Evaluated: heart rate (HR), Parasympathetic Function (HF) and Function Friendly and influence Parasympathetic (LF), Balance sympathetic / parasympathetic (LF / HF), systolic blood pressure (SBP) and diastolic (DBP) and Respiratory Rate (FR). The DLE phases, SEDT and the transition between them were compared in each trimester. The transitional period and both times were also compared separately according to gestational age. The moments $0 \mathrm{~min}$ (A), 10min (B) and $20 \mathrm{~min}$ (C); were also faced, and finally comparing the quarters 1 (D) 2 (E) and 3 (F). Statistical analysis was applied to Friedman's analysis of variance. Results: Compared to the steps (0min- x10min- DLE DLE / SEDT x20min- SEDT) in the 1st quarter, there was no significance for HR, SBP, DBP and FR. In the 2nd quarter, when analyzed times (0min- x10min- DLE DLE / SEDT x20min- SEDT) with each other, not reach significance the variables HR, SBP, DBP, RF and LF / HF ratio. By analyzing the times (0min- $x 10 \mathrm{~min}-\mathrm{DLE}$ DLE / SEDT x20min- SEDT) of the 3rd quarter, it was for HR, SBP, DBP, RF and LF / HF values without significance. Conclusion: This study indicates the existence of significant changes in the autonomic nervous system and cardiorespiratory.
\end{abstract}

Keywords: Autonomic function; Pregnant; Autonomic Nervous system; Pregnancy; Heart rate variability.

\section{RESUMO}

Introdução: A gravidez caracteriza-se por mudanças fisiológicas relacionadas à formação de um ambiente ideal para o feto. Nesse período não é incomum ocorrerem desvios da normalidade, assim como, desequilíbrio entre os diversos sistemas orgânicos, sobretudo, o sistema nervoso autônomo, o que pode acarretar em situações patológicas. Objetivo: Avaliar a função autonômica e cardiovascular em gestantes de acordo com o tempo de gestação no 1으, 2으 e 3ำ trimestre, através do estudo da Variabilidade da Frequência Cardíaca (VFC). Método: Foram avaliadas 20 gestantes cadastradas em uma Unidade Básica de Saúde. O protocolo foi dividido em duas fases com duração de 10 minutos em decúbito lateral esquerdo (DLE) e 10 minutos em sedestação (SEDT). Avaliados: Frequência Cardíaca (FC), Função Parassimpática (HF) e Função Simpática e influência Parassimpática (LF), Balanço Simpático/Parassimpático (LF/HF), Pressão Arterial Sistólica (PAS) e Diastólica (PAD) e Frequência Respiratória (FR). As fases DLE, SEDT e o período de transição entre elas foram comparados em cada trimestre gestacional. O período de transição e os dois momentos também foram comparados separadamente de acordo com o tempo de gestação. Os momentos $0 \mathrm{~min}(\mathrm{~A}), 10 \mathrm{~min}(\mathrm{~B})$ e $20 \mathrm{~min}(\mathrm{C})$; também foram confrontados, e por fim, comparados os

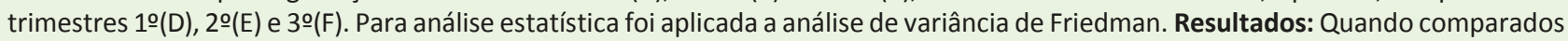
às etapas (0min- DLE x10min-DLE/SEDT x20min-SEDT) no $1^{\circ}$ trimestre, não houve significância para FC, PAS, PAD e FR. No $2^{\circ}$ trimestre, quando analisados os tempos (0min- DLE x10min-DLE/SEDT x20min-SEDT) entre si, não obtiveram significância as variáveis FC, PAS, PAD, FR e a relação LF/HF. Ao analisar os tempos (0min- DLE x10min- DLE/SEDT x20min- SEDT) do $3^{\circ}$ trimestre, verificou-se para FC, PAS, PAD, FR e LF/HF valores sem significância. Conclusão: O presente estudo indica a existência alterações significativas no sistema nervoso autônomo e cardiorrespiratório das gestantes.

Palavras-chave: Função autonômica; Gestante; Sistema nervoso autônomo; gravidez; Variabilidade da frequência cardíaca.

\footnotetext{
Corresponding author: Alan Carlos Nery dos Santos. Av. Luís Viana Filho 3146. Campus Prof. Barros - Norte. Paralela, Zip Code: 41.720-200, Salvador (BA), Brazil. E-mail: allannery.santos@hotmail.com

${ }^{3}$ Physical therapy course of Universidade Salvador (UNIFACS), Salvador (BA), Brazil.

Full list of author information is available at the end of the article.
}

Financial support: None.

Submission date 3 July 2015; Acceptance date 25 October 2015; Online publication date 4 November 2015 


\section{INTRODUCTION}

Pregnancy is characterized by physiological changes related to the formation of an ideal environment for the fetus. Due to the complexity of the mechanisms involved, it is not uncommon deviations occur during normal pregnancy. The side effects of pregnancy status require adjustments and do not constitute a threat to the mother's health if performed properly. It is known that an imbalance between the various body systems, especially the autonomic nervous system, resulting in disease. ${ }^{(1,2)}$

The adaptations that occur in the cardiovascular system during pregnancy are among the reasons enable greater oxygen supply, a compensation for the increased demand in this situation. ${ }^{(2)}$ It is known that the autonomic and cardiac factors are physiologically involved. ${ }^{(3)}$ Thus, pregnant women who have autonomic dysfunction are prone to develop heart disease, stimulated by hyperactivation of the SNS (sympathetic nervous system) that contributes to various deleterious effects characteristic of pregnant women causing morbidity and mortality. ${ }^{(4,5)}$

The Heart Rate Variability (HRV) is considered a predictor of morbidity and mortality. ${ }^{(6-10)}$ Using the Polar heart rate monitor $\mathrm{S} 810^{\circledR}$, non-invasive method used in clinical practice, one can investigate the autonomic function by detecting this variation. As the sympathetic activity, parasympathetic and cardiac factors are related and dysfunction of the ANS can cause diseases justifies this study in pregnant women. ${ }^{(11)}$

Thus, the objectives of this study were to study the autonomic function during pregnancy according to gestational age in the first, second and third quarter; and to compare each patient the behavior of the three quarters in relation to the autonomic function by studying the HRV.

\section{METHODS}

This is a prospective study, composed of 20 pregnant women studied with respect to the autonomic function on first, second and third trimester. These were assessed in the sector Gynecology and Obstetrics of the Basic Health Unit in the South Zone of São Paulo, from March to October 2006. It was considered as a criterion for inclusion women in the first trimester of pregnancy and had the possibility of They are monitored throughout pregnancy. Patients with conditions that hamper monitoring as well as those referred to another service, integrated the exclusion criteria.

The study was approved by the Research Ethics Committee on Hospiral Geral do Grajaú/Universidade de Santo Amaro (UNISA), São Paulo, SP, Brazil (013/2006). All patients were informed of the study characteristics and signed informed consent and informed participation in the research.

We used a questionnaire containing identification, history and physical examination, and a record of attendance containing registration data for patient's name, date of assessment, age, time markers starting at 0 minutes, ranging from 5 in 5 minutes for all the variables analyzed. Was used Cardiac Monitor (Polar S810 ${ }^{\circledR}$ ), consisting of an infrared transmitter coupled to an elastic strap and Polar ${ }^{\circledR}$ Software Precision Performance ${ }^{\circledR}$, for the record HRV and consequent analysis of heart rate (HR), sympathetic activities that influence the parasympathetic (LF and HF), parasympathetic (HF) and the relationship of activity Sympathetic / parasympathetic (LF/HF). To measure the systolic blood pressure (SBP) and diastolic blood pressure (DBP), we used stethoscope (Littmann Master Cardiology) and sphygmomanometer (GAMMA ${ }^{\circledR}$ HEINE G5) with clamp.

Before being monitored, the patients remain in the initial rest for 20 minutes. This resting time was tapped to carry out the medical history with the questionnaire. After the rest period, the patients underwent monitoring of the behavior of autonomic function, through the record of HRV, the following variables: SBP, DBP, Respiratory Rate (RR) and HR, LF, HF and LF/HF. All patients were met individually and in the morning due to the circadian cycle. ${ }^{(12)}$

The behavior of autonomic function was recorded during a period of twenty minutes, divided in two stages: the first time lasting 10 minutes in the position in Left Side decubitus (LSD) and the second time with 10 minutes duration in the sitting position (SIT). The first transitional period for the second time was also recorded by the monitor. The procedure was performed by placing a chest strap attached to the electromagnetic transmitter Polar $\mathrm{S} 810^{\circledR}$.

For the measurement of autonomic function was used HRV, recorded by Polar S810 ${ }^{\circledR}$ device, validated ${ }^{(13)}$ Data were analyzed using the Software Polar ${ }^{\circledR}$ Precision Performance ${ }^{\circledR}$ and complemented by analysis of the software Matlab. - MathWorks version 6.5. The HR signals were also recorded by Polar $S 810^{\circledR}$ and analyzed through the apparatus of the program.

The SBP and DBP were meansured during cardiac monitoring the first and second moments as well as in the transition period these using the sphygmomanometer. The RR was recorded in the medical record.

For the analysis of the results was applied to Friedman variance analysis, ${ }^{(14)}$ studying the variation in the three trimesters of pregnancy and the three times of the exam. It was fixed at 0.05 or $5 \%$ would lead to rejection of the null hypothesis.

HRV was performed in the field of frequency, the spectral analysis. ${ }^{(27)}$

\section{RESULTS}

For the variables $H R, S B P, D B P, R R, L F, H F$ and LF / HF results both times were presented separating into three steps: 0 minutes or 1st stage (early stage in left side position), 10 minutes or 2 nd stage (transfer from left side position to sitting position) and 20 minutes or 3 rd stage (final stage on sitting position). 
When compared to the steps (0 min - LSD x $10 \mathrm{~min}$ LSD / SIT x 20 min - SIT) on 1st trimester of pregnancy, there was no significance for $H R, S B P, D B P$ and $R R$. In the same context we obtained significant data: $L F(p=0.05)$, a reduction of their activity in time $10 \mathrm{~min}$ - transition from LSD posture to SIT compared to the times Omin - start of monitoring in LSD, and 20min - end position in SIT; HF ( $p=0.02)$, with its activity in time $0 \mathrm{~min}$ - start of monitoring in DLE, decreased compared to the times 10min - LSD to SIT, and $20 \mathrm{~min}$ - SIT; and LH/HF ( $p=0.001$ ) observed that an increase of this variable in time 10 mins (transition from LSD to SIT) and 20min when compared to the time of 0 min monitoring.

Compared to the 2 nd quarter, when analyzed times ( 0 min LSD x 10min - LSD / SIT x 20min - SIT) with each other, not reach significance the variables $H R, S B P, D B P, R R$ and LF / HF ratio. Significant values were found to LF ( $p=0.001)$, an increase in this activity in the times $0 \mathrm{~min}$ - LSD and 20min - SIT over time 10min - LSD / SEDT; and HF ( $p=0.02)$ with an increase of its influence in time 0min - LSD, when compared to the 10 minutes time - LSD/SIT, and 20min - SIT.

By analyzing the times (0 min - LSD x 10min - LSD / SIT $x$ $20 \mathrm{~min}$ - SIT) of the 3rd quarter, it was for HR, SBP, DBP, RR and $\mathrm{LF} / \mathrm{HF}$ values without significance. There was significance to LF $(p=0.05)$ decrease in this activity at 10 minutes compared to time 0 and 20 minutes; and HF ( $p=0.001$ ) with depletion of this variable in the time 10 and 20 minutes compared to time $0 \mathrm{~min}$.
Table 1 shows, according to the 1 st stage (0min) - start of monitoring in LSD, which to exchange the quarters $(1 \times 2 \times 3)$ were registered data without significance for $H R, S B P, D B P$, $R R$ and LF. Significant numbers were found to HF $(p=0.02)$ in which there was an increase of its values in the 1st quarter compared to the other two; and LF/HF ( $p=0.05)$ increase in this activity in Q3.

At the intersection of data the quarters $\left(1^{\circ} \times 2^{\circ} \times 3^{\circ}\right)$ for 10 minutes from time, seen in Table 2, were not found significant numbers for HR, SBP, DBP, RR, LF and LF/HF. Significant value was found for: $H F(p=0.02)$ with high activity in the 1st quarter compared to the other two, the analysis of the transition from left lateral decubitus posture to sitting.

In Table 3, the analysis of $20 \mathrm{~min}$ - Final monitoring in SEDT to the permutation of the quarters $\left(1^{\circ} \times 2^{\circ} \times 3^{\circ}\right)$ has observed no significant findings for SBP, DBP, LF and LF/HF. Significant values were recorded for: $\mathrm{HR}(p=0.05)$ increase in its share in the 3rd quarter compared to the 1st Quarter; FR ( $p=0.01$ ) with high activity in the 2 nd and 3 rd quarter compared to the 1st quarter; and HF ( $p=0.01)$ with depletion of its values in the 2 nd and $3 r d$ quarter compared to the 1 st quarter.

\section{DISCUSSION}

HRV is the result of interaction between various systems, such as respiratory, endocrine, musculoskeletal and highlighted in this study, the Autonomic Nervous System, specifically the sympathetic nervous system (SNS) and the parasympathetic

Table 1. Friedman's analysis of variance $\left(X^{2} r\right)$ in the three trimesters of pregnancy according to the mean and median of the variables of time 0 minutes, São Paulo (SP), 2015.

\begin{tabular}{|c|c|c|c|c|c|}
\hline \multicolumn{6}{|c|}{$0 \mathrm{~min}$} \\
\hline Variables & & 1ำtrim & 2o-trim & 3trim & Friedman's analysis of variance \\
\hline \multirow{2}{*}{$\mathrm{HR}$} & Mean & 83.30 & 89.30 & 93.80 & $X^{2} r=3.79$ \\
\hline & Median & 84.00 & 88.50 & 93.00 & NS \\
\hline \multirow{2}{*}{ SBP } & Mean & 116.00 & 115.00 & 117.50 & $X^{2} r=1.11$ \\
\hline & Median & 120.00 & 110.00 & 120.00 & NS \\
\hline \multirow{2}{*}{ DBP } & Mean & 75.75 & 71.50 & 72.50 & $X^{2} r=2.61$ \\
\hline & Median & 80.00 & 70.00 & 70.00 & NS \\
\hline \multirow{2}{*}{$\mathrm{RR}$} & Mean & 17.70 & 19.85 & 20.15 & $X^{2} r=4.59$ \\
\hline & Median & 17.00 & 20.00 & 20.50 & NS \\
\hline \multirow{2}{*}{ LF } & Mean & 31.13 & 23.43 & 25.33 & $X^{2} r=1.20$ \\
\hline & Median & 26.40 & 23.75 & 25.80 & NS \\
\hline \multirow{2}{*}{$\mathrm{HF}$} & Mean & 20.98 & 16.02 & 15.08 & $X^{2} r=9.10 p=0.02$ \\
\hline & Median & 17.60 & 13.55 & 9.55 & 10trim $>2$-trim e 3 otrim \\
\hline \multirow{2}{*}{$\mathrm{LF} / \mathrm{HF}$} & Mean & 2.21 & 2.28 & 2.41 & $X^{2} r=6.30 p=0.05$ \\
\hline & Median & 1.56 & 1.34 & 2.45 & $3^{\circ}$ trim $>1$-trim e $2 \circ$ trim \\
\hline
\end{tabular}

HR: Heart rate; SBP= Systolic Blood Pressure; DBP= Diastolic Blood Pressure; RR= Respiratory rate; LF e HF= Sympathetic activities influence the parasympathetic; HF= Parasympathetic activity; $\mathrm{LF} / \mathrm{HF}=$ Sympathetic/Parasympathetic Activity ratio (LF/HF); 0 minuto or 1 a phase = Early stage in the left lateral decubitus position; NS= Not significant (statistically); $\mathrm{X} 2 \mathrm{r}=$ nonparametric test; $p \leq 0,05$ ou $5 \%$ the level of rejection of the null hypothesis. 
nervous system (PNS). HRV can be divided on the methodology for analyzing temporal and spectral analysis, the second choice because it is a study of individuals in home conditions. ${ }^{(15,16)}$

There were variations in the vacant-sympathetic modulation, with stimulation of the sympathetic activity and reduced parasympathetic effect on the heart in the study of change in posture. The LSD transfer to a sitting position promotes cardiac changes due to hydrostatic changes. Seeking greater reliability for data collected in this work it was decided to complete all procedures in the morning, as the autonomic behavior presents circadian cycle, suffering physiological variations during the day that could affect results. ${ }^{(12,15,16)}$

Table 2. Friedman analysis of variance $\left(X^{2} r\right)$ in the three trimesters of pregnancy according to the mean and median of the variables studied time 10 minutes, São Paulo (SP), 2015.

\begin{tabular}{|c|c|c|c|c|c|}
\hline \multicolumn{6}{|c|}{10 minutes } \\
\hline Variables & & 19-trim & 29-trim & 3ำtrim & Friedman's analysis of variance \\
\hline \multirow{2}{*}{$\mathrm{HR}$} & Mean & 83.70 & 90.30 & 91.50 & $X^{2} r=4.30$ \\
\hline & Median & 82.50 & 88.50 & 91.00 & NS \\
\hline \multirow{2}{*}{ SBP } & Mean & 120.00 & 116.50 & 116.50 & $X^{2} r=2.49$ \\
\hline & Median & 120.00 & 115.00 & 120.00 & NS \\
\hline \multirow{2}{*}{ DBP } & Mean & 78.75 & 72.75 & 72.50 & $X^{2} r=5.56$ \\
\hline & Median & 80.00 & 70.00 & 70.00 & NS \\
\hline \multirow{2}{*}{ RR } & Mean & 17.70 & 18.60 & 19.05 & $X^{2} r=4.49$ \\
\hline & Median & 18.00 & 18.00 & 20.00 & NS \\
\hline \multirow{2}{*}{ LF } & Mean & 20.85 & 17.30 & 18.41 & $X^{2} r=3.10$ \\
\hline & Median & 19.70 & 18.45 & 20.25 & NS \\
\hline \multirow{2}{*}{$\mathrm{HF}$} & Mean & 13.42 & 11.79 & 8.26 & $X^{2} r=9.10 p=0.02$ \\
\hline & Median & 13.55 & 8.75 & 6.45 & 19-trim > 2ำtrim e $3^{\circ}$ trim \\
\hline \multirow{2}{*}{$\mathrm{LF} / \mathrm{HF}$} & Mean & 3.03 & 2.58 & 2.58 & $X^{2} r=4.80$ \\
\hline & Median & 1.36 & 2.24 & 2.64 & NS \\
\hline
\end{tabular}

HR: Heart rate; $\mathrm{SBP}=$ Systolic Blood Pressure; $\mathrm{DBP}=$ Diastolic Blood Pressure; RR= Respiratory rate; $\mathrm{LF}$ e HF= Sympathetic activities influence the parasympathetic; HF= Parasympathetic activity; LF/HF= Sympathetic/Parasympathetic Activity ratio (LF/HF); 10 minutes or $2^{\text {a }}$ phase = Transition from left lateral decubitus position to the position of sedestation; NS= Not significant (statistically); $X 2 r=$ nonparametric test; $p \leq 0,05$ ou $5 \%$ the level of rejection of the null hypothesis.

Table 3. Friedman analysis of variance $\left(X^{2} r\right)$ in the three trimesters of pregnancy according to the mean and median of the variables studied time 20 minutes, São Paulo (SP), 2015.

\begin{tabular}{|c|c|c|c|c|c|}
\hline \multicolumn{6}{|c|}{20 minutes } \\
\hline Variables & & 1ㅇtrim & 2otrim & 3trim & Friedman's analysis of variance \\
\hline \multirow{2}{*}{$\mathrm{HR}$} & Mean & 83.10 & 87.85 & 90.55 & $X^{2} r=7.41 p=0.05$ \\
\hline & Median & 85.00 & 86.00 & 90.00 & 19-trim < 3ㅇtrim \\
\hline \multirow{2}{*}{ SBP } & Mean & 120.50 & 117.50 & 119.00 & $X^{2} r=1.72$ \\
\hline & Median & 120.00 & 115.00 & 120.00 & NS \\
\hline \multirow{2}{*}{ DBP } & Mean & 76.25 & 72.25 & 74.50 & $x^{2} r=1.93$ \\
\hline & Median & 80.00 & 70.00 & 70.00 & NS \\
\hline \multirow{2}{*}{$\mathrm{RR}$} & Mean & 17.50 & 18.65 & 19.45 & $X^{2} r=9.82 p=0.01$ \\
\hline & Median & 17.00 & 19.00 & 19.00 & 1ㅇtrim $<2$ o e 3 o trim \\
\hline \multirow{2}{*}{ LF } & Mean & 24.74 & 21.27 & 20.85 & $X^{2} r=2.10$ \\
\hline & Median & 23.95 & 20.35 & 21.75 & NS \\
\hline \multirow{2}{*}{$\mathrm{HF}$} & Mean & 13.75 & 10.88 & 8.82 & $X^{2} r=11.92 p=0.01$ \\
\hline & Median & 12.60 & 10.60 & 8.45 & 10 trim $>2{ }^{\circ}$ trim e $3^{\circ}$ trim \\
\hline \multirow{2}{*}{$\mathrm{LF} / \mathrm{HF}$} & Mean & 4.03 & 3.18 & 2.67 & $X^{2} r=2.80$ \\
\hline & Median & 1.73 & 2.24 & 2.52 & NS \\
\hline
\end{tabular}

HR: Heart rate; SBP= Systolic Blood Pressure; DBP= Diastolic Blood Pressure; RR= Respiratory rate; LF e HF= Sympathetic activities influence the parasympathetic; $H F=$ Parasympathetic activity; $\mathrm{LF} / \mathrm{HF}=$ Sympathetic/Parasympathetic Activity ratio (LF/HF); 20 minutes or 3 a phase= Finals position in sedestation; NS= Not significant (statistically); $\mathrm{X} 2 \mathrm{r}=$ nonparametric test; $p \leq 0,05$ ou $5 \%$ the level of rejection of the null hypothesis. 
In this study there was a reduction of parasympathetic activity (HF) in changing LSD position to SIT, significant from the 1st to the 2nd and 3rd quarter, this finding supported by several authors. In sitting posture was no significant increase in HR from the 1st to the 3rd trimester. These results are supported by authors who cite the increased heart output because the heart increases in size and accommodate more blood; then the stroke volume increases and cardiac output increases of $30-50 \%$ there is a progressive increase in the mean heart during pregnancy. ${ }^{(1,2,5)}$

When compared to the times: early monitoring / LSD (0 $\mathrm{min}$ ), transition LSD / SIT. (10min) and final monitoring in SIT (20 min), it was observed that the action of LF is greater than in supine decubitus position change phase for SIT with significant results to the 1 st, 2 nd and $3 r d$ quarter. On the 2 nd and 3 rd quarter the weight of the fetus can compress the aorta and inferior vena cava, lying down, activating the autonomic nervous system, with predominant stimulation of sympathetic activity, supporting the results for $\mathrm{LF}^{.}(4,8,9)$

There were no significant results for SBP and DBP when compared LSD and SIT times; probably because pregnant women were at rest during cardiac monitoring. There was also no difference in the behavior of these variables in the 1st, 2nd and 3 rd quarter accordance with the literature, which cites that blood pressure may or may not fall quietly in the 2 nd trimester of pregnancy, maintaining normal in the 1st and Q3..$^{(8,17)}$

Regarding the RR in pregnant women, it is known that the average respiratory resting increases slightly - from 15 to 18 breaths per minute approx. Studies indicate that in SIT position, increased RR observed in the 2 nd and 3rd quarters are due to the fetus pressure toward the diaphragm, also affecting the ribs of pregnant women, causing them to dilate, which may explain the increase found among the patients in this study. ${ }^{(1,18,19)}$

During pregnancy the respiratory excursion is limited in the lung bases and the largest movement is observed in the apical and mesocostal regions and women often experience considerable breath shortages, even in modest efforts, like home in the sitting position, towards the end of pregnancy. $(18,20)$ This is a relevant fact as changes in the RR may also make changes in HRV. ${ }^{(21-23)}$

The median of 28.50 years for the age of pregnant shows the late situation that these women are getting pregnant, which is a propensor factor for triggering heart disease. The literature reports that HRV has significant change in function of age, including being a biological marker of aging. When age-related, HRV becomes a parameter predictor of morbidity and mortality from heart disease. ${ }^{(19,24,25)}$

\section{CONCLUSION}

According to the evaluation and comparison of the results there are changes in the ANS, specifically depletion of the parasympathetic activity and likely increased sympathetic activity, and cardiorespiratory changes in pregnant women. Although HRV is considered a predictor of morbidity and mortality, such changes are physiological for pregnancy, and there is therefore, in this study, propensity to onset of cardiovascular disease during pregnancy. Still, it takes strategy for the proper monitoring of cardiovascular and respiratory risk factors in this population.

\section{AUTHORS CONTRIBUTION}

Conception and design of the research: Araújo WS, Mantese JC, Sigulem MD; Data collection: Araújo WS, Cury MC, Sigulem MD; Analysis and interpretation of data: Gardenghi G, Mantese JC, Oliveira FTO, Petto J, Cury MC, Sigulem MD; Statistical analysis: Mantese JC, Gardenghi J, Petto J; Manuscript Writing: Araújo WS, Petto J, Santos ACN, da Mata CS; Critical revision of the manuscript on the intellectual content: Gardenghi G, Petto J, Santos ACN, Araujo WS, Mantese JC, Oliveira FTO.

\section{COMPETING INTERESTS}

The authors declare no conflicts of interest.

\section{AUTHOR DETAILS}

${ }^{1}$ Faculdades integradas (UNESULBAHIA), Eunápolis (BA), Brazil. ${ }^{2}$ Physical therapy course of Faculdade Social da Bahia (FSBA), Salvador (BA), Brazil. ${ }^{4}$ Post-graduation course in Saúde Materno Infantil da Universidade de Santo Amaro (USA), São Paulo (SP), Brazil. ${ }^{5}$ Postgraduate Course in Fisioterapia Hospitalar do Hospital e Maternidade São Cristóvão, (GO), Brazil.

\section{REFERENCES}

1. Artal R; Wiswell RA, Drinkwater BL. O exercício na gravidez. 2a ed. São Paulo: Manole, 1999.

2. Finkelstein I, Bgeginski R, Tartaruga MP, Alberton CL, Kruel LFM. Comportamento da freqüência cardíaca e da pressão arterial, ao longo da gestação, com treinamento no meio líquido. Rev Bras Med Esporte. 2006;12(5):376-80.

3. Guyton, A. Tratado de Fisiologia Médica. Elsevier, 11ạ edição 2006.

4. Swansburg ML, Brown CA, Hains SM, Smith GN, Kisilevsky BS. Maternal cardiac autonomic function and fetal heart rate in preeclamptic compared to normotensive pregnancies. Can J Cardiovasc Nurs. 2005;15(3):42-52.

5. Fischer T, Schobel HP, Frank H, Andreae M, Schneider KT, Heusser K. Pregnancy-induced sympathetic overactivity: a precursor of preeclampsia. Eur J Clin Invest. 2004 Jun;34(6):443-8.

6. Grupi CJ, Brito FS, Uchida AH. Eletrocardiograma de longa duração: o sistema holter - parte II. Reblampa. 1999;12(3):134-46.

7. Sakabe DI, Catai AM, Neves VFC, Oliveira L, Silva de Sá MF, Azevedo $\mathrm{GB}$, et al. Análise da modulação do coração durante condições de repouso em homens de meia-idade e mulheres pós-menopausa. Rev Bras Fisioter. 2004;8(1):89-95.

8. Faber R, Baumert M, Stepan H, Wessel N, Voss A and Walther T. Baroreflex sensitivity, heart rate, and blood pressure variability in hypertensive pregnancy disorders. J Hum Hypertens. 2004 Oct;18(10):707-12.

9. Walther T, Wessel N, Baumert M, Stepan H, Voss A and Faber R. Longitudinal Analysis of Heart Rate Variability in Chronic Hypertensive Pregnancy. Hypertens Res. 2005 Feb;28(2):113-8.

10. Radespiel-Tröger M, Rauh R, Mahlke, C, Gottschalk T, Mück-Weymann M. Agreement of two different measurement of heart rate variability. Clin Auton Res. 2003;13:99-102.

11. Rajendra Acharya U, Paul Joseph K, Kannathal N, Lim CM, Suri JS. Heart rate variability: a review. Med Bio Eng Comput. 2006;44(12): 1031-51.

12. Kardelen F, Akçurin G, Ertuğ H, Akcurin S, Bircan I. Heart rate variability and circadian variations in type 1 diabetes mellitus. Pediatr Diabetes 2006; 7:45-50. 
13. Acharya UR, Kannathal N, Hua LM, Yi LM. Study of heart rate variability signals at sitting and lying postures. J Bodywork Mov Theraphies. 2005;9(2):134-41.

14. Siegel S. e Castellan N. J Jr. Nonparametric statistics. 2 nd edition, New York: McGraw-Hill; 1988.

15. Rocha RM, Albuquerque DC, Filho FMA. Variabilidade da frequência cardíaca e ritmo circadiano em pacientes com angina estável. Revista da SOCERJ. 2005;18(05):429-42.

16. Pumprla J, Howorka K, Groves D, Chester M, Nolan J. Functional assessment of heart rate variability: physiological basis and practical applications. Int J Cardiol. 2002;84:1-14.

17. Del Bene R, Barletta G, Mello G, Lazzeri C, Mecacci F, Parretti E, et al. Cardiovascular function in pregnancy: effects of posture. BJOG. 2001 Apr;108(4):344-52.

18. Nogueira AA, Reis FJC, Reis PAS. A paciente gestante: na unidade de terapia intensiva. Medicina, Ribeirão Preto. 2001;34:123-132.

19. Paschoal MA, Volanti VM, Pires CS, Fernandes FC. Variabilidade de frequência cardíaca em diferentes faixas etárias. Rev Bras Fisioter. 2006;10(4):413-9.
20. Paschoal MA, Petrelluzzi KFS, Gonçalves NVO. Estudo da variabilidade da frequência cardíaca em pacientes com doença pulmonar obstrutiva crônica. Rev. Ciênc. Méd. 2002;11(1):27-37.

21. Silva VJD de, Januário EM. Variabilidade da freqüência cardíaca e da pressão arterial na insuficiência cardíaca congestiva. Rev. bras. Hipertens. 2005;12(1):21-26.

22. Ribeiro FT, Cunha A, Lourenço GCD, Marães VRFS, Catai AM, Gallo Jr $L$, et al. Estudo da variabilidade da frequência cardíaca em dois voluntários de meia-idade, um coronariopata e outro saudável - Relato de caso. Rev Soc Cardiol Estado de São Paulo. 2000;10:1-10.

23. Machado MGR, Aroeira RMC, Assumpção JA. Alteração do sistema respiratório na gravidez. In: Baracho E. Fisioterapia aplicada à obstetrícia. Aspectos de ginecologia e neonatologia. 3a ed. Rio de Janeiro: Medsi, 2002.

24. Spiropoulos K, Prodromaki E, Tsapanos V. Effect of body position on $\mathrm{PaO} 2$ and $\mathrm{PaCO} 2$ during pregnancy. Gynecol Obstet Invest. 2004;58(1):22-5

25. Bootsma M, Swenne CA, Van Bolhuis HH, Chang PC, Cats VM, Bruschke AV. Heart rate and heart rate variability as indexes of sympathovagal balance. Am J Physiol. 1994 Apr;266(4 Pt 2):H1565-71. 